\title{
ETHNOGRAPHIC LEGACIES: NIKO KURET
}

\author{
Ingrid Slavec Gradišnik
}

\begin{abstract}
Niko Kuret was one of the most crucial personalities in Slovenian ethnology in the second half of the 20th century. Interested in a variety of subjects, he was nevertheless closest to ethnography even in the period before the Second World War. Although his ethnological research commenced in the late 1940s, he was not able to fully immerse himself in it until his full-time employment at the Institute of Slovenian Ethnology in 1954.

Rather than Kuret's infrequent explicit statements about theoretical research in ethnography, it was his research plan that represented the basis for founding the Commission for Slovenian Ethnography in 1947, his participation in discussions about future orientations in ethnology, his organizational work, and his methodological instructions that clearly indicate what ethnography/ ethnology meant to him and what purpose he saw in it. His research on social and spiritual life and culture, the methodology of which was essentially that of cultural history, expresses his principles and ideological orientation. In this respect, Kuret was an heir to ethnographic tradition. This can be seen from his methodological approach to folk culture as well as his opinion that its elements and values should be made familiar to the public. Yet as a scholar with diverse knowledge, well versed in scholarly production in Slovenia and abroad, and a participant in international scholarly discussions, Niko Kuret was able to follow, and accept, new trends in contemporary ethnology. These, however, he preferred to leave to his younger colleagues.
\end{abstract}

Key words: Niko Kuret (1906-1996), ethnology in Slovenia.

To speak about Niko Kuret's ethnological horizon means speaking about horizons in the plural, simply because of the numerous and diverse aspects of Kuret's interests and research topics - from the very beginning of his work and later in ethnology and folklore studies, including their borders and beyond. This characterizes not only his personal interests, but also his professional and scholarly pursuits.

From the somewhat narrower aspect of ethnology, in terms of Kuret's scholarly career it is essential to draw attention to the significance of developed institutional ramification for the life of the discipline and scholars within it. Immediately after the Second World War, Kuret was also involved in this joint creative effort in the most direct manner. It is the men that were first engaged on a part-time basis and then hired full time at central institutions of ethnology 


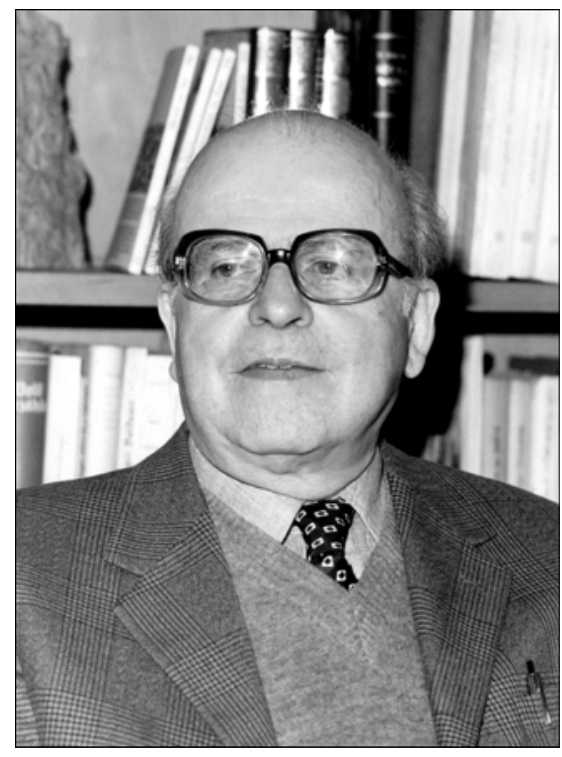

that contributed the most to the gradual consolidation of what was previously a marginal discipline, if it was even accorded such a status at all. In short, no matter how trivial it seems, a scholar can develop and exist only in a scholarly institution. If the Second World War is some kind of relevant landmark, it is because ethnology - at that time generally referred to as ethnography (or narodopisje in Slovenian $)^{1}$ - only then obtained its complete institutional apparatus (in scholarship and education at the university, and in research at the Academy of Sciences and Arts) and began to extend its roots and gradually take on a stronger role in museums as well. By definition, these institutions are a place for the argumentation of a discipline itself, and it was justifiably expected that the experts of that time considered their work and the physiognomy of the discipline that they were developing first of all within its autonomous institutions.

Very generally, at least until the end of the Second World War, it was characteristic of ethnographic activity and research that, on the one hand, its horizon was based on a (world) view that more or less jointly shaped ethnography as a "salvage project" under the currents of civilization and the pressure of disappearing folk culture, but on the other hand efforts to strengthen professionalism and positivist academic methodology in cultural and historical comparative variants were evident at the same time, at least from the work of Matija Murko onwards. The institutional background was weak and it was especially noticeable that in Slovenia there was no university program in ethnology. ${ }^{2}$ Everyone that is considered part of the ethnographical/ethnological research tradition today was educated in other branches of study; the majority was philologists connected to Murko's philology, which also offered a very special place to ethnology. ${ }^{3}$

Kuret's academic oeuvre still belongs to the time of the prevailing ethnographical paradigm, explicitly developed by Murko, and which stubbornly persisted well into the decades following the Second World War, ${ }^{4}$ when, on the other hand, different concepts of ethnology and folklore studies began to be established. ${ }^{5}$ The period immediately after the Second World War was a turning point; as already mentioned, initially not as a radical conceptual change but 
primarily from the institutional perspective and because of the visible efforts made by the specialists of that time to strengthen ethnological and folklore studies in Slovenia.

In this regard, in connection with Kuret's work in the period prior to 1954 - when he finally officially became a full-time researcher at the Institute, after first working as an external associate of the Commission for Slovenian Ethnography (later renamed Inštitut za slovensko narodopisje/Institute of Slovenian Ethnology) -, France Kotnik's review in the Survey of Slovenian Ethnography in 1944 is very indicative. On the one hand, he described Kuret as someone who popularized narodopisje and, on the other hand, as one who "tried to lay the conceptual foundations of ethnographic work" (Kotnik 1944: 46).

Everything mentioned so far draws attention to the fact that Kuret's prewar work was not solely amateurism or quasi-professionalism, as one could conclude on the basis of his exceptionally diverse work, which nonetheless was mostly very close to the issues of folk life. Perhaps this is most evident in connection with his interest in folk theater and guiding it; that is, his work in publishing the collection Ljudske igre (Folk Plays) and the periodical Ljudski oder (Folk Stage). ${ }^{6}$ Later on, in the 1950 s, this topic was also addressed in his scholarly articles. The same is also true of his articles on seasonal customs, carnival costumes, and literary tradition. He summarized his views of that time in his article "Naši narodni običaji - naš najlepši zaklad" (Our National Customs Our Most Beautiful Treasure) in the Sloven čev koledar (Slovenian Almanac) of 1943 (Kuret 1943). This article formed the basis for Kotnik's review mentioned above.

The article, which was directed towards a relatively large audience, principally discusses the meaning of customs in the life of a community, but to ethnologists it reveals even more: Kuret writes about the disastrous effects of civilization as the external forces of progress (new inventions, rapid technological development, and economic liberalism), radically changing the life of nations since the industrial revolution. This separated the people from their fields and relocated the workers into factories through their desire to earn more money; becoming, according to Kuret, "trivial, gray, nervous, and exhausted. Everywhere there is haste, bitterness, and hatred." However, Kuret saw a possibility here for the old and new times to reconcile. In the folk tradition that was still alive he saw values that stood up to the superior force of civilization; these are the Christian values that direct man's annual life cycle, offer ideals connected to the "patriarchic community of a healthy and more or less well-off home rooted in the Slovenian soil"; that is, to the family, neighborhood, village, or parish. His ethnographic efforts aimed to educate the nation: 
A national educational work in the best sense of the term means when we strive to bring all this treasure back to life, to unearth the buried parts; to restore its original meaning where it has been deformed; to give it a modern form where it has strayed.

An ethnographer is thus not only a collector and recorder of folk tradition, but also a mediator of knowledge regarding these values, someone that helps establish them in the everyday lives of people. Decades later, Kuret, as a mature researcher and a man with a feeling for the changes in life, adopted a reserved approach towards his somewhat activist statement of that time:

In the past, we really meant to 'revive customs.' However, we came to realize this is a problematic issue... In general, this kind of 'revival' requires a certain extent of spiritual preparedness and communal foundation. With religious customs this is harder to achieve today in Slovenia - and not only in Slovenia. It is different with profane customs (Kuret and Fikfak 1985: 183-184). ${ }^{7}$

"The reconstruction of folk culture" on this ideological basis certainly gave meaning to Kuret's entire work; however, it cannot be stated that it explicitly limited his academic profile in any way - or perhaps only to the extent the personal views and habitus of a researcher influence his academic work, because in a particular way they certainly define his selection of topics, special orientations, and methodology.

Within this framework, Kuret's role in providing for the entire physiognomy and activity of the discipline of ethnology in the postwar decades should be emphasized. During this period, together with his colleagues Ivan Grafenauer, Boris Orel, Milko Matičetov, Vilko Novak, and Sergij Vilfan, ${ }^{8}$ he tried to institutionally strengthen and ramify ethnological research so that it would be comparable to that practiced abroad. ${ }^{9}$ In doing so, it was necessary to literally overtake or jump over the missed steps.

He wrote about this while he was documenting the history of the Institute of Slovenian Ethnology (and the Institute's history is mostly also his own history). He played a key role in this because it was he that designed the research program for the Commission for Slovenian Ethnography, established in 1947, in a letter accompanying the plan for the "Slovenian Ethnological Dictionary" or the "Slovenian Ethnological Archive". 10

Kuret's concern for ethnographic material in the form of records of all cultural material, including tangible and social culture, with alphabetically arranged keywords and explanations in lexical style, a subject bibliography, and illustrative material, grew into a systematic plan for the research institution. The main 
items of this plan, expanded in the Commission's articles of association, demonstrate Kuret's view of the discipline, his breadth, and his systematicity:

1. Collecting ethnographic material in the field - manuscripts, prints, historical documents, estate materials, and so on - and comparable material among the other Slavic as well as the neighboring Germanic and Romance nations;

2. Coordinating and supporting related institutions with similar tasks;

3. Arranging and storing this material in an archive for the national literary, musical, and fine arts, an archive of Slovenian social culture and an archive of Slovenian material folk culture;

4. Scholarly publications of the material and using the material for scholarly studies and preparation of important works on ethnography and ethnogenesis, as well as for the preparation of popular encyclopedic publications;

5. Supporting the preservation of "ethnographic monuments" in Slovenia in the field, in museums, and so on;

6. Promoting ethnographic study in secondary and professional schools, as well as at the university. (Kuret 1947)

Because of numerous unfavorable circumstances, ${ }^{11}$ this ambitious plan was not carried out.

Although we do not wish to underestimate the work of other associates, it was Kuret's work that came closest to the tasks described in the program. ${ }^{12}$

In field collection, the Institute started working with the Ethnographic Museum as early as the late 1940s in field research teams organized by Boris Orel. Because of the limited possibilities of this kind of research ${ }^{13}$ Kuret was aware that material should also be collected in some other way. Thus the Institute began preparing questionnaire ${ }^{14}$ that were distributed throughout Slovenia to gather new information. For this purpose and in order to establish a direct connection with the work in the field, to promote surveys and the creation of a network of reporters, Niko Kuret initiated the publication of the Glasnik Inštituta za slovensko narodopisje (Institute of Slovenian Ethnography Newsletter), which later on became the journal of the Slovene Ethnographical Society and, even later, Slovene Ethnological Society (Glasnik Slovenskega etnološkega društ$v a$ / Bulletin of the Slovene Ethnological Society). A decade and a half later, he was also among the founders of the Institute's scholarly journal Traditiones (since 1972), and also worked as its editor.

The following note by Kuret also refers to concern for the material, which at that time was considered the primary and most important task: 
The historical direction of the discipline and the present state [---] required not only the collection but also a downright rescue of the old material. It was necessary to archive the disappearing tradition. (Kuret 1973a: 24)

Kuret was aware of the dilemma of a researcher caught between collection and research (classification, analysis, and interpretation of material):

It is therefore understandable if occasionally, when there was not much time, the idea occurred that collecting and rescuing the material takes precedence over research, saying that death does not wait, old people are dying and taking their knowledge with them into the grave - let's therefore leave research to the next generation! (Kuret 1973a: 24)

When the material collected by the first nine field teams of the Ethnographic Museum was exhibited at the Ljubljana Gallery of Modern Art in 1953, Kuret felt that folk culture - towards which the new, socialist order generally assumed a quite ambivalent attitude - and its research had their own raison d'être.$^{15} \mathrm{It}$ is up to each individual to decide how much romanticism, or what would be called exoticism today, is bound up in this. However, this search for the other in oneself is a universal feature, which anthropologists, ethnologists, ethnographers, and folklorists deal with in a different way in every generation.

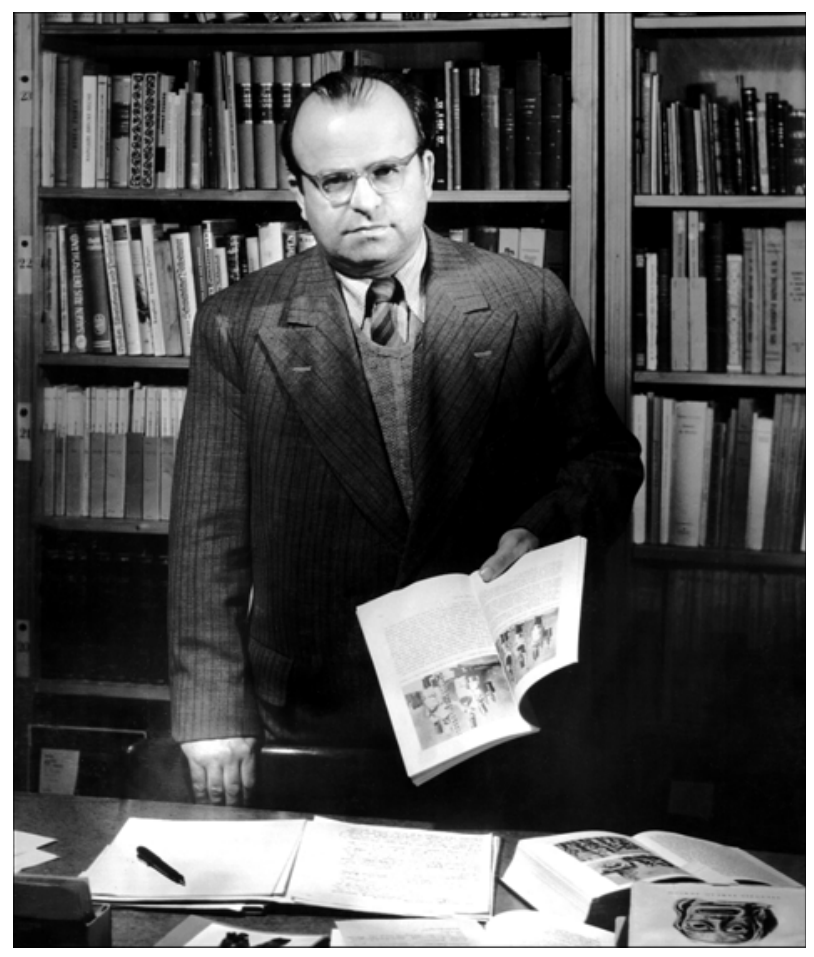


When we wish to emphasize Kuret's broad interest in the scholarly foundations of ethnography or ethnology, in connection with material and its use, as well as disseminating its findings, we cannot overlook his concern for the bibliography - not only Slovenian, but also its inclusion in the international bibliography (Kuret himself was member of the international editorial boards of the Internationale Volkskundliche Bibliographie and Demos) - and new documentation methods. Here it must be stressed that Kuret was among the first to make use of film in ethnology. ${ }^{16}$

The first postwar generation of ethnologists strove for the scholarly approach primarily within a methodological framework (exhaustiveness, systematics, documentation); Kuret was one of the few that wrote down specific instructions for ethnographic practice (he published short texts about this at the beginning of the 1960s in Glasnik SED, Kuret 1961a, b, c). Regarding the definition of the research problem itself, however, they more or less clung to the definition of folk culture as a culturally, historically, and regionally differentiated, lower cultural stratum (with its [proto-]Slavic, Mediterranean, Alpine, Pannonian, and Balkan elements). This was the first relativization of the ethnic concept of the 'folk' that directed research projects, but it was by no means a new one.

The concept of a two- or three-layered form of culture was not new to Slovenian ethnographers. For example, Kuret's contemporary Vilko Novak was fairly skeptical towards the theory of disappearing cultural assets and adhered to the view of accepting and adjusting to other (foreign) cultural assets to be the essence of folk culture or the folk. On the other hand, Kuret mostly thought of a trickling of elements from high into folk culture as a constituent part of its image, but also ascribed the most important role to folk creativity. Elements taken from high culture "were experiencing changes in line with folk tastes and needs; they have become folk assets" (Kuret 1951: 248). Kuret tried to prove this with debates on folk drama, plays, and customs. It was similar to what researchers today, using slightly different terminology, are discovering in the case of the global-local relationship.

The second relativization of the concept of folk culture was created by the social and psychological definition of the 'folk', which operates with the elementary human orientation towards collective life and according to traditional principles. This enables reflection on folk culture in the present as well. Kuret focused this point of departure into an entirely psychological definition, which enabled him to think about following folk life in the present. The 'folk' is thus that which is constant in the inconstant and which can be revealed through structuralist principles. 
Specifically, Kuret wrote:

I see a psychological category in the folk, and not a sociological or any other category, ... the folk corresponds to the mother, the naïve, and every human psyche, that is, the immanent layer, and as such does not know any difference in the sex, age, and social or historical background of an individual (Kuret 1978b: 20).

To Kuret, inconstancy was somehow external and socially determined; however, the phenomenon itself - for example, carnival masking - remains universally human. He was convinced that social changes, for example, inevitably lead to a different typology of costumes and the disappearance of archaic rituals; the psychological need to carnival costumes, however, remains important and constant.

This certainly does not mean that Kuret's ethnography changes into a psychology of the collective unconscious, but instead it fits neatly into the classical concept of cultural history as the history of spiritual wealth that cannot be conceived of without a psychological foundation.

However, it must be acknowledged that in his point of departure Kuret was close to phenomenology and structuralism. He nonetheless primarily followed the cultural and historical paradigm because at that time it probably corresponded more to the issues and problems he and his colleagues were involved with. It was connected to the research priorities established by the institute; that is, the image of origins, characteristics, and changes in traditionally defined Slovenian folk culture.

With these principles that by no means have a priori hypostatized folk culture, in the 1960s and 1970s Kuret joined in several ongoing debates by Slovenian ethnologists and folklorists on the subject of ethnography (i.e., folk culture), ethnological research plans and the status of ethnology, the relationship between ethnology and folklore studies, the status of the "ethnology of the present" or research on the present in ethnology, and so on. He also took part in the majority of significant ethnological projects, including those encouraged and carried out by the somewhat younger generation of ethnologists. Kuret's name is thus found among those that participated in the Vprašalnice ETSEO (Questionnaires for the Ethnological Topography of Slovenian Ethnic Territory), in the volumes Pogledi na etnologijo (Views on Ethnology) and Slovensko ljudsko izročilo (Slovenian Folk Tradition), and in the Slovenski etnološki leksikon (Slovenian Ethnological Lexicon). He also tried to see eye to eye with those with different views. He allowed them to tread their own paths, similar to what Vilko Novak did with his students. 
Kuret did not reject ethnological research on the modern way of life, which received greater emphasis in the research programs of the 1970s onwards, but he was not particularly in favor of it either. In connection to this orientation (as though he were somewhat undecided), he sometimes mentioned cultural history and at other times sociologically and psychologically based cultural anthropology, which ethnography should use to cope with the circumstances

that arise with phenomena created by industrialization and the application of technology, as well as by political changes in individual countries... A situation has emerged in which the ethnographer will no longer be allowed to deal with the remnants of the old folk culture alone, but will also have to study people as the bearers of social and cultural functions in the complicated network of constantly differentiating living areas (Kuret 1965a: 302).

Thus, in his own way, Kuret joined in the critique of ethnography as the study of peasant life and admitted the incapacity of classical ethnographical apparatus to investigate contemporary culture. He indicated a kind of a methodological separation between research on folk culture in the past and on modern culture or life. He ascribed the first to "historical ethnography" and the latter to the "newly oriented ethnography," which he believed was closer to American cultural anthropology. Objections to this methodology were based on epistemological arguments (Kremenšek 1965 a, b), but by formulating traditional ethnological interest on the one hand and interest in contemporary life on the other, it seems that Kuret was not thinking so much of its theoretical argumentation, but was more pragmatic. What he had in mind were research tasks and challenges that have not been carried out yet and whose continuity he already perceived from the work of Matija Murko onwards (Kuret 1968).

In his "historical ethnography," Kuret was in favor of and also employed the monographic principle of research and interpretation. This corresponded to the thematic specializations of that time and the interpretative sample of comparable cultural history or cultural and historical methodology. The following steps were used: a detailed description of the phenomenon or cultural element discussed, facts about the origin, development, distribution in the European cultural area (occasionally also beyond its boundaries), frequency of variants, analysis of features and connections in terms of content and typology (for example, in terms of motif), as well as conclusions concerning the origin, development, and, usually, the decay of the phenomenon studied. This model is seen in several of Kuret's works, most clearly in his monograph on the štehvanje tradition of the Gail Valley (Sln. Zilja) (1963). 
Since the 1960s, cultural and historical methodology has been subjected to historical/genetic or dialectical/materialistic criticism. The predominantly presentist approach saw in it fewer positive and more negative elements of the disciplinary tradition. ${ }^{17}$ However, it must be stressed that cultural and historical interest envisioned ethnography with a comparative perspective. In Kuret's research (and also research done by others) on everything that was connected to the annual holiday, or calendar cycle and the movement of people through it, this perspective reinforced an important recognition that separated this kind of research from a fascination with ethnographic pittoresque; that is, that the numerous special features of people that were considered unique cease to be special if we look at them broadly or with a view from afar. In short, by definition the ethnic paradigm was relativized with comparativeness.

The group among which Kuret was most definitely one of the leading figures carried this out as early as the 1950s within the informal group of researchers called Alpes Orientales, which studied the culture of Alpine countries. This group created a dialogue between Swiss, Austrian, Italian, and Slovenian ethnologists, which was very important for the development of the discipline. However, after nearly two decades dialogue was discontinued. As a watchful observer, Kuret wrote:

Sooner or later we will have to occasionally look into the present as well and see the changes that the end of the 20th century has already brought about and is still bringing about. We cannot treat the Eastern Alps as a historical ethnological museum forever. (Kuret 1973b: 264)

Because Kuret (and his generation) was not especially in favor of theory, the implicit or background conceptual and theoretical framework of his work must be read between the lines, in introductory and concluding chapters of his works, and certain articles with more explicitly designed concepts. This is not the place to cite numerous statements on the relationship between ethnological theory and practice, but there is one that seems to express the most:

I think my generation has not been especially oriented towards theory. When we went out in the field, we were flooded by an abundance of still unknown and unrecorded material, and we simply put aside all theoretical reflection. We would say to ourselves: 'People are dying, but theory will still be there!' Some held that against us. (Kuret and Fikfak 1985: 184)

With these words Niko Kuret, in a straightforward manner, expressed what was at that time observed in more critical evaluations of the development of Slovenian ethnology and folklore studies concerning the relationship between 


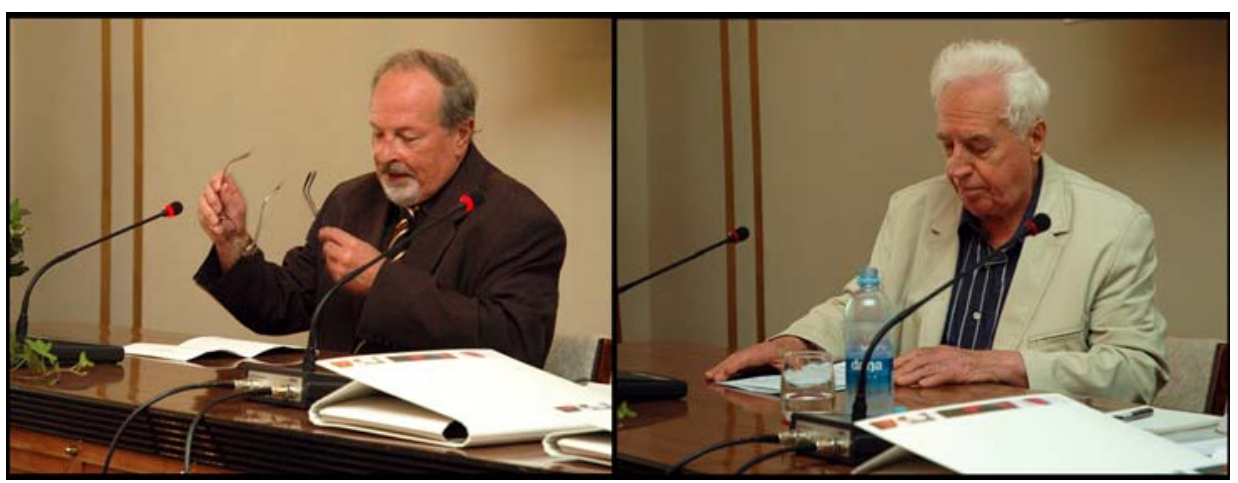

Primoš Kuret and Milko Matičetov delivering their papers at the conference dedicated to Niko Kuret. Photo by Juri Fikfak.

their respective theory and practice. This relationship can be viewed from several perspectives:

- We can primarily view it as a lack of theory or disciplinary self-reflection or even hatered to theory (i.e., Theoriefeindlichkeit as used by Bausinger); or

- as an abyss between theory and the demands of practice (ethnography); moreover, between the rhetoric of textbooks and everyday practice; between the normative and the real; or

- as a way of creating theory out of practice, or as the "addition principle", a concretist or complementary method (Terseglav 1983) that contributes to generalizations on the basis of contributing constantly new empirical findings.

It appears that all three reasons worked for Kuret. Generally speaking, empiricist research according to subject, method, and goals was characteristic of ethnographic tradition, in contrast to conceptually and theoretically based research; for the first, a canonical definition of various disciplines was sufficient. Kuret's definition of ethnography thus also remained general, as "research on folk culture in all its forms."

Priority was given to empiricism with the following reasons: the primary task was to collect everything that was slowly falling into oblivion. Collecting enthusiasm was so strong that there was not enough time to think about a solid conceptual and methodological framework, which today is understood as constant circulation between empiricism and theory.

This approach is characteristic of "traditional" science: one that deals with the specifics and details of an object (a field) sufficiently also arrives at structural relations that he or she then formulates with general principles; the guarantee for this transition or "jump" is sufficient experience (Detela's 6th thesis). 
Niko Kuret had a great deal of life, professional, and academic experience that influenced his academic work, perhaps more than anyone else in his generation. His breadth documented in his essays thus remains an almost unattainable ideal to all his successors. He proved it through research projects on numerous subjects evident from his exceptional bibliography, with comments and evaluations, during numerous travels and dialogues in Slovenia and abroad. Kuret's international horizon, his contacts with researchers abroad, the foreign scholarly literature that he read, his knowledge of the cultural tradition of ritual and the spiritual life of Slovenians in Europe that he also supplied to the European scholarly community ${ }^{18}$ - all of this should be part of a special study because it influenced the breadth of his views and enabled him to engage in discourse with practically anyone.

\section{Comments}

${ }^{1}$ The Slovenian term narodopisje does not completely correspond to the English term ethnography because the semantic breadth of the latter is considerably broader today. The term narodopisje more closely corresponds to the German term Volkskunde.

2 The university program began just before World War II, in 1940. During the war courses were essentially dormant, and only really took off after the war, although with very insufficient staffing.

${ }^{3}$ Cf. Slavec Gradišnik (2000) and relevant sources cited therein.

${ }^{4}$ Regarding the tradition of the ethnological discipline, a differentiated attitude was perceptible in Slovenia: an affirmative one (among the older researchers, who were born in the first two decades of the 20th century and entered the field of ethnology or folklore studies mostly as established philologists), as well as a critical and almost negative attitude among younger researchers. However, by taking into account a more thorough study of the development of this discipline, even this image has become increasingly differentiated in the last few years.

5 "Ethnology and folklore studies" because in Slovenia there was a debate on whether these are two completely autonomous disciplines (which folklorists have been and are still striving for) or merely one; that is, ethnology, a vital part of which is also the study of folklore, for which folklore studies developed a series of special, interdisciplinary methods. Within this context the scope or definition of folklore studies is also debatable (from the narrowest sense of literary folklore studies to the broadest sense of the study of traditional culture as a whole).

${ }^{6}$ The bibliography of ethnological publications from 1934 to 1944 contains articles on folk theater, calendar customs, carnival masks, and literary tradition.

7 In this sense his later research actually had resonance in the fields where this kind of spiritual preparedness was present; for example, it was most evident in the reconstruction of the carnival tradition. His monograph Maske slovenskih pokrajin 
(Masks of Slovenian Regions, Kuret 1984) is thus a special manual, as is his exceptional four-volume work entitled Praznično leto Slovencev (The Festive Year of the Slovenians, Kuret 1965-1971).

${ }^{8}$ Ivan Grafenauer was head of the Commission and later of the Institute of Slovenian Ethnology, Boris Orel was the director of the Ljubljana Ethnographic Museum, Milko Matičetov was initially an associate at the Ethnographic Museum and later the Institute of Slovenian Ethnology, Vilko Novak was an assistant instructor and later a lecturer at the Ethnology Department of the Ljubljana Faculty of Arts, and Sergij Vilfan was the museum's external associate, a lawyer, and later a professor at the Faculty of Law.

9 Witness is borne to this by his rich correspondence with experts abroad, writing for international scholarly publications, taking part in international professional and scholarly meetings, and his care to include the Slovenian ethnological bibliography in the international bibliography (Internationale Volkskundliche Bibliographie, Demos).

10 This is one of the first documents in the institute's archive, which was reprinted in the original and in an expanded form in the first volume of the institute's journal Traditiones (Kuret 1972: 9-14)

11 The circumstances are documented in a greater detail in the ISE Archive and described in its history (Kuret: 1972, 1973). The main reason was the number and specializations of individuals that worked at the academy's institute. Caring for material culture was entirely taken over by the Ethnographic Museum, whereas until the 1970s the institute mainly specialized in literary tradition, plays, and customs.

${ }^{12}$ Kuret already began copying ethnographic information out of Slovenian periodicals while he was working as an external associate of the institute (officially from 1950 onwards). What and how much he documented is evident from his reports submitted for the payment of fees (ISE Archive; cf. Kuret 1972: 13, 15).

${ }^{13}$ This was not classic field methodology or ethnography in the sense that researchers stay in the field for an extended period of time, but (e.g., in the case of the Ethnographic Museum field teams) research that lasts for several weeks or, in other cases, multiple or repeated visits to a selected location, event, or informants.

14 The first questionnaire sent to secondary schools in 1953 inquired about the addresses of good storytellers, the burning of yule logs, and folk inscriptions. This was followed by questionnaires on children's games, exhuming corpses and washing the skull, grain sprouted at New Year, evergreens and other house decorations, costumes, and so on.

15 "One would think that because of major issues and tasks in broader circles the pace of modern life has repressed or even stifled interest in our folk culture, which ethnography discovers and researches. But this is wrong... The common man and the intellectual instinctively feel that irreparable damage would be done if any of this material disappeared without a trace. Not many people would know how to explain this, but everybody is convinced of this... The exhibition thus aroused some kind of a latent interest and even more: the hidden deep love of the Slovenian people towards everything ethnography deals with. Ethnographers feel a strong satisfaction here. Their belief that they are working not only for collections and archives, the journals 
in libraries, and publications intended for scholars, has been confirmed; the people stand behind them and follow their efforts with gratitude (Kuret 1954: 302-303).

${ }^{16}$ This activity of Kuret's was analyzed, evaluated, and commented on by Naško Križnar on several occasions (1995, 1996, 1997, 2006). Kuret's most important articles are collected or reprinted in the volume Etnološki film med tradicijo in vizijo (Ethnological Film between Tradition and Vision, ed. by Križnar, 1997).

${ }^{17}$ If we were to carefully follow the vocabulary of Andre Gingrich, we could even hold this tradition to be "non-tradition: I... use nontradition in a double sense - to refer, on one hand, to dispersed, hidden, and half-forgotten treasures with little continuity and, on the other, to certain schools with a lot of continuity that, however, do not represent any positive tradition today" (Gingrich 2005: 61). The ethnographic paradigm has a tradition of not merely several decades, but of a century or even more. Without repeating and/or encouraging the criticism to which it was subjected, it is completely clear that to Kuret the "ethnographic program" of Matija Murko was some sort of orientation even for modern Slovenian ethnology.

${ }^{18}$ A translated selection of his articles published abroad was published in Opuscula selecta (Kuret 1996).

\section{References}

Gingrich, Andre. 2005. The German-Speaking Countries. In: Barth, F., A. Gingrich, R. Parkin, \& S. Sylverman. One Discipline, Four Ways. British, German, French, and American Anthropology. Chicago \& London: Chicago University Press, pp. 61-153.

Kotnik, France. 1944. Pregled slovenskega narodopisja [Survey of Slovenian ethnography]. In: Ložar, Rajko (ed.). 1944. Narodopisje Slovencev I. Ljubljana: Klas, pp. 2152 .

Kremenšek, Slavko. 1965a. Kulturnoantropološka načela [Principles of Cultural Anthropology]. Naši razgledi (Ljubljana) 14 (329, 25 Sept. 1965), p. 367.

Kremenšek, Slavko. 1965a. Metodološke dileme [Methodological Dilemmas]. Naši razgledi 14 (332, 6 Nov. 1965), p. 433.

Križnar, Naško. 1995. Niko Kuret in slovenski etnografski film [Niko Kuret and Slovenian Ethnographic Film]. Etnolog (Ljubljana), 5 (56), pp. 71-102.

Križnar, Naško. 1996. Vizualne raziskave v etnologiji [Visual Research in Ethnology]. Ljubljana: ZRC SAZU (= Zbirka ZRC 15).

Križnar, Naško. 1997. Obdobje po Kuretu. Med tradicijo in vizijo [The Period after Kuret. Between Tradition and Vision of the Future]. In: Križnar, Naško (ed.).Etnološki film med tradicijo in vizijo. Ljubljana: ZRC SAZU, Založba ZRC, pp. 127-131.

Križnar, Naško. 2006. Kuretova dediščina etnografskega filma. Etnografski film v preobilju vizualnega / Kuret's Legacy. Ethnographic Film in Abundance of the Visual. In: Slavec Gradišnik, Ingrid \& Jurij Fikfak (eds.). 2006. Ljudsko izročilo in religija med tradicijo in transformacijo. Povzetki / Folklore and Religion between Tradition and Transformation. Abstracts. Ljubljana and Celje: ZRC SAZU, Inštitut za slovensko narodopisje, pp. 35-37.

Kuret, Niko. 1943. Naši narodni običaji - naš najlepši zaklad [Our National Customs - Our Most Beautiful Treasures]. Slovenčev koledar (Ljubljana), 1943, pp. 41-42. 
Kuret, Niko. 1947. Slovenski narodopisni slovar - Slovenski narodopisni arhiv [Slovenian Ethnographical Dictionary - Slovenian Ethnographical Archive] (typescript). (Arhiv ISN / Archive of the ISE).

Kuret, Niko. 1954. Etnografska razstava v Ljubljani [Ethnographic Exhibition in Ljubljana]. Slovenski etnograf (Ljubljana), 6-7, pp. 301-305.

Kuret, Niko. 1961a. Etnografovi tehnični pripomočki [Ethnographer's Technical Devices]. Glasnik SED (Ljubljana) 3 (1), p. 3.

Kuret, Niko. 1961b. Vprašanje etnografskih informatorjev [The Question of Ethnographic Informants]. Glasnik SED 3 (2), pp. 9-10.

Kuret, Niko. 1961c. Pota do narodopisnega gradiva [Paths to Ethnographic Material]. Glasnik SED 3 (3-4), pp. 15-16.

Kuret, Niko. 1965. Nove smeri v nemškem narodopisju [New Trends in German Ethnography]. Naši razgledi 15 (326, 7 Aug. 1965), pp. 302-303.

Kuret, Niko. 1965-1971. Praznično leto Slovencev [The Festive Year of the Slovenians], 4 vol. Celje: Mohorjeva družba.

Kuret, Niko. 1968. Stanje slovenskega narodopisja [The State of Slovenian Ethnography]. Glasnik SED 9 (3), pp. 1-4.

Kuret, Niko. 1972. Naša 25-letnica. Komisija (1947-1951) in Inštitut za slovensko narodopisje SAZU (od 1951). Nastanek, razvoj, delo [Our 25th Anniversary. The Commission for (1947-1951) and Institute of Slovenian Ethnology (1951-). Beginnings, Development, Work]. Traditiones, 1, pp. 9-18.

Kuret, Niko. 1973a. Naša 25-letnica. Komisija (1947-1951) in Inštitut za slovensko narodopisje SAZU (od 1951). Nastanek, razvoj, delo (Nadaljevanje) [Our 25th Anniversary. The Commission for (1947-1951) and Institute of Slovenian Ethnology (1951-). Beginnings, Development, Work (Continuation)]. Traditiones, 2, pp. 5-33.

Kuret, Niko. 1973b. "Alpes Orientales" 6 (Thusis - Tusaun 1970) in 7 (Brixen Bressanone 1972). Traditiones 2, pp. 263-264.

Kuret, Niko. 1978a. O šegi in njeni spremenljivosti [On Custom and Its Changeability]. In: Kremenšek, Slavko \& Angelos Baš (eds.). 1978. Pogledi na etnologijo. Ljubljana: Partizanska knjiga, Filozofska fakulteta, pp. 309-333.

Kuret, Niko. 1978b. Konec folkloristike? [The End of Folklore Studies?]. Glasnik SED 18 (1), p. 20.

Kuret, Niko. 1984. Maske slovenskih pokrajin [Masks of Slovenian Regions]. Ljubljana: Cankarjeva založba.

Kuret, Niko. 1996. Opuscula selecta. Poglavja iz ljudske kulture [Opuscula Selecta. Chapters on Folk Culture]. Ljubljana: SAZU.

Ložar-Podlogar, Helena. 1979. Bibliografija etnoloških Nika Kureta [Ethnological Bibliography of Niko Kuret]. Traditiones, 5-6 (1976-1977), pp. 121-146.

Ložar-Podlogar, Helena. 1986. Bibliografija Nika Kureta 1977-1985 [Bibliography of Niko Kuret 1977-1986]. Traditiones, 15 (1986), pp. 271-274.

Ložar-Podlogar, Helena. 1996. Bibliografija Nika Kureta 1986-1995 (z dopolnilom za leto 1985) [Bibliography of Niko Kuret 1986-1995 (with supplements for 1985)]. Traditiones, 25 (1996), pp. 471-474.

Novak, Vilko. 1995. Življenje, osebnost, raziskovalno delo in pomen Nika Kureta za slovensko etnologijo in kulturo [The Life, Personality, Research and Importance of Niko Kuret for Slovenian Ethnology and Culture]. Etnolog 5 (66), pp. 51-70. 
Slavec Gradišnik, Ingrid. 2000. Etnologija na Slovenskem. Med čermi narodopisja in antropologije [Ethnology in Slovenia. Between the Reefs of narodopisje and Anthropology]. Ljubljana: Založba ZRC, ZRC SAZU.

Terseglav, Marko. 1983. Težnje v povojni slovenski folkloristiki [Trends in Slovenian Folklore Studies after the Second World War]. In: Bogataj, Janez \& Marko Terseglav (eds.) 1983. Zbornik 1. kongresa jugoslovanskih etnologov in folkloristov. Ljubljana: Slovensko etnološko društvo, pp. 176-203. 